\title{
Synergetic effect of sewage sludge and biomass co-pyrolysis: a combined study in thermogravimetric analyzer and a fixed bed reactor
}

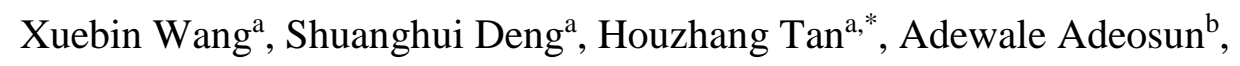 \\ Milan Vujanović ${ }^{\mathrm{c}}$, Fuxin Yang ${ }^{\mathrm{a}}$, Neven Duić ${ }^{\mathrm{c}}$ \\ ${ }^{a}$ MOE Key Laboratory of Thermo-Fluid Science and Engineering, Xi'an Jiaotong University,
}

Xi'an, Shaanxi, 710049, China

${ }^{b}$ Department of Energy, Environmental \& Chemical Engineering, Washington University in St. Louis,

St. Louis, MO 63130, USA.

${ }^{c}$ Faculty of Mechanical Engineering and Naval Architecture, University of Zagreb, 10000 Zagreb, Croatia

The information of corresponding author: tanhz@mail.xjtu.edu.cn, +86-029-82668703

\begin{abstract}
Much attention has been given to the valuable products from sewage sludge pyrolysis. In this study, the pyrolysis of sewage sludge, biomass (wheat straw) and their mixtures in different proportions were carried out in a thermogravimetric analyzer (TGA) and fixed-bed reactor. The effects of pyrolysis temperature and percentage of wheat straw in wheat straw-sewage sludge mixtures on product distributions in terms of gas, liquid and char and the gas composition were investigated. Results indicate that there is a significantly synergetic effect during the co-pyrolysis processes of sewage sludge and wheat straw, accelerating the pyrolysis reactions. The synergetic effect resulted in an increase in gas and liquid yields but a decrease in char yield. The gas composition and the synergetic effect degree are strongly affected by the wheat straw proportions, and the strongest synergetic effect of sewage sludge and wheat straw co-pyrolysis appears at the biomass proportion of $60 \%$. With an increase of temperature, the gas yield from sewage sludge pyrolysis increased but the liquid and char
\end{abstract}


yields decreased. Moreover, the required heat of co-pyrolysis is significantly reduced compared with the pyrolysis of sewage sludge and wheat straw pyrolysis alone, because of the exothermic reactions between the ash components in two fuel samples.

Keywords: Sewage sludge, Biomass, Pyrolysis, Synergetic effect, DSC

\section{Introduction}

Sewage sludge is the solid waste generated in the municipal and industrial wastewater treatment plants worldwide. With the rapid development of urbanization and industrialization, the production of sewage sludge has been dramatically increased. The improper disposal management of sewage sludge increases many environmental and economic problems and causes air, water and soil pollutions. This is because of the presence of harmful and toxic substances existed in sewage sludge, such as viruses, bacteria, dioxins, nonbiodegradable organic compounds, heavy metals ,and so on [1]. In addition, high nitrogen content in sewage sludge will cause a serious concern for combustion processes and produce $\mathrm{NO}_{\mathrm{x}}$ waste gases [2]. The composition of sewage sludge depends on the sewage disposal systems in the wastewater treatment plant, but the sewage sludge generally contains high levels of organic matters and proteins, which endow the capability to produce hydrogen [3]. After drying, the sewage sludge contains around 5-10 wt.\% of water, $15-30$ wt. $\%$ of carbohydrates, 2-17 wt.\% of fats or lipids, $10-21$ wt.\% of proteins and $30-50$ wt.\% of inorganic matter [4]. Dried sewage sludge can be regarded as a kind of biomass fuel, largely because of its considerable volatile content (30-88 wt.\%) and calorific value (typically 11-25.5 MJ/kg) [5].

There are many conventional methods used to treat sewage sludge, such as farmland application and sewage sludge disposal in landfills and oceans. However, these methods can also cause serious pollution accidents or need high treatment costs, and are not environmentally friendly or cost-effective. Among the various sewage sludge management options, pyrolysis is a kind of 
effective and potential methods to solve these problems, through producing gas, bio-oil and char while avoiding the formation of toxic organic compounds [6]. Bio-oils from pyrolysis are referred to as pyrolysis liquids, pyrolysis oils or bio-crude oils [7]. Pyrolysis can produce clean gas and bio-oils compared to incineration. However, the single pyrolysis of sewage sludge can hardly produce high quality fuels due to high moisture and ash contents. In the pyrolysis gas, the sizeable proportion of $\mathrm{CO}_{2}$ greatly decreases the heating value [8]. The high moisture yield obtained from the pyrolysis of sewage sludge also causes the low quality of bio-oil [9]. Compared with the other solid fuels, the solid residues (char) from the pyrolysis of sewage sludge have relatively low heating values due to the high content of ashes existed in sewage sludge [10].

In contrast, biomass is a valuable renewable energy resource because of its high volatile matters and low ash content. Considering the high contents of moisture and ash in sewage sludge, the co-pyrolysis of sewage sludge and biomass might be an effective method because biomass addition enhances the energy utilization of sewage sludge and improves the properties of different pyrolysis products [11]. Under a series of proper cleaning treatments, these pyrolysis products can be directly used in electro-heat equipments, such as gas turbines, boiler and fuel cells. The liquid produced by the pyrolysis of sewage sludge is a complex mixture including the nitrogen- and sulfur-containing compounds. If the liquid is used as fuel, it may lead to $\mathrm{NO}_{\mathrm{x}}$ and $\mathrm{SO}_{2}$ emission problems. These problems would be relieved if sewage sludge and lignocellulosic biomass were co-pyrolyzed [12]. Moreover, the heating value of bio-oil from co-pyrolysis would be also improved due to the higher heating value of biomass. There have been many studies on the pyrolysis of sewage sludge and biomass mixtures to investigate the existence of synergetic effects [13, 14]. Samanya et al. [15] studied the upper phase with high organic compound contents in bio-oil obtained from the 
co-pyrolysis processes of sewage sludge with wood, rapeseed and straw. It was found that the effect of co-pyrolysis on bio-oil was strongly affected by the biomass fuel types. Huang et al. [16] observed that the addition of rice straw increased the performance of microwave heating and proposed that the reason could be attributed to the synergetic effect. Zhu et al. [17] presented that there was no significant synergetic effect existed during the thermal decomposition of mixed sewage sludge and pine sawdust by thermogravimetric analysis. Salleh et al. [18] reported that the co-cracking of sewage sludge and rice waste did not significantly reduce the bio-oil yield from the individual rice waste samples in a fluidized-bed pyrolytic reactor. It can be seen that there is still no unified conclusion on the synergetic effects existing in co-pyrolysis process of sewage sludge and biomass due to the differences of pyrolysis conditions such as reactor types, temperature, fuel types and heating rate. The studies on the caloric requirement of the co-pyrolysis of sewage sludge with biomass are few, despite the fact that it is important for the energy balance design in the potential co-pyrolysis facilities.

The aim of this work is to convert sewage sludge into valuable products and therefore find a potential solution for sewage sludge management. In this work, the co-pyrolysis experiments of sewage sludge and biomass (wheat straw) were carried out in a TGA and fixed-bed reactor to study the synergetic effect and to determine the optimum operating conditions of the co-pyrolysis processes by measuring the three-phase (gas/liquid/solid) product distributions, the gas composition, and the pyrolysis heat required.

\section{Samples and methods}

\subsection{Samples}

Sewage sludge used in this study was obtained from a wastewater treatment plant in Xi'an, 
Shaanxi Province, China. The wastewater contains municipal wastewater and industrial wastewater. The industrial wastewater which comes from the textile, printing, dyeing, and mechanical working industries accounts for $55.3 \%$, while municipal wastewater which comes from residential, institutional and commercial establishments accounts for $44.7 \%$. Wheat straw was taken as the representative material of biomass. The wheat straw was collected from a farm around Xi'an in Shaanxi Province, China. Sewage sludge and wheat straw were dried at $105{ }^{\circ} \mathrm{C}$ for $24 \mathrm{~h}$ in the oven. The ultimate and proximate analysis is shown in Table 1. The dried sewage sludge and wheat straw samples were milled and sieved into 50-200 $\mu \mathrm{m}$ in diameter. Dried sewage sludge and wheat straw were well mixed together, with wheat straw weight percentages of 20, 40, 60 and $80 \%$, respectively.

Table 1 Ultimate and proximate analysis of two samples

\begin{tabular}{|c|c|c|c|c|c|c|c|c|c|c|}
\hline \multirow{2}{*}{ Samples } & \multicolumn{5}{|c|}{ 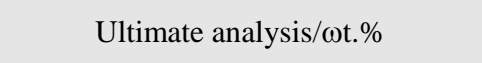 } & \multicolumn{4}{|c|}{ Proximate analysis $/ \omega t . \%$} & \multirow{2}{*}{$\begin{array}{c}\mathrm{LHV} / \mathrm{MJ} \cdot \mathrm{kg}^{-1} \\
\mathrm{Q}_{\text {net,ad }}\end{array}$} \\
\hline & $\mathrm{C}_{\mathrm{ad}}$ & $\mathrm{H}_{\mathrm{ad}}$ & $\mathrm{O}_{\mathrm{ad}}$ & $\mathrm{N}_{\mathrm{ad}}$ & $\mathrm{S}_{\mathrm{ad}}$ & $\mathrm{M}_{\mathrm{ad}}$ & $\mathrm{V}_{\mathrm{ad}}$ & $\mathrm{FC}_{\mathrm{ad}}$ & $A_{a d}$ & \\
\hline Sewage sludge & 29.12 & 5.98 & 21.04 & 3.98 & 1.64 & 4.57 & 63.13 & 5.47 & 26.83 & 16.70 \\
\hline Wheat straw & 43.92 & 4.47 & 40.98 & 0.44 & 0.30 & 3.88 & 72.1 & 18.01 & 6.01 & 14.77 \\
\hline
\end{tabular}

$\left(\mathrm{M}_{\mathrm{ad}}\right.$ : moisture as air dried basis; $\mathrm{V}_{\mathrm{ad}}$ : volatile matter as air dried basis; $\mathrm{FC}_{\mathrm{ad}}$ : fixed carbon as air dried basis; $\mathrm{A}_{\mathrm{ad}}$ : ash as

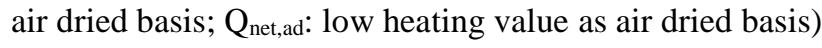

\subsection{Experimental apparatus and procedure}

Thermogravimetric analysis on the co-pyrolysis of sewage sludge and wheat straw was conducted in a STA-409PC thermal analyzer (NETZSCH, German). For each test, approximately 10 mg of material sample was placed into a alumina crucible and heated from $30{ }^{\circ} \mathrm{C}$ to $1000{ }^{\circ} \mathrm{C}$ at a constant heating rate of $20{ }^{\circ} \mathrm{C} \cdot \mathrm{min}^{-1}$ in nitrogen atmosphere with a flow rate of $100 \mathrm{ml} \cdot \mathrm{min}^{-1}$. All the samples were tested at the same conditions to be comparable. The curves of thermogravimetric mass loss (TG), differential thermogravimetric (DTG) and differential scanning calorimetry (DSC) are recorded and produced on line by using the bundled software with the analyzer. 
The experiments of co-pyrolysis focusing on the product distributions and the gas composition were carried out in a fixed-bed reactor with a length of $1000 \mathrm{~mm}$ and internal diameter of $40 \mathrm{~mm}$. The experimental system is shown in Fig. 1. This system consisted of a quartz reactor, a temperature control unit, a nitrogen control unit, a condensation unit for the condensable water and oil, a gas filter and dryer unit for cleaning and drying gases, a metering and analyzing unit for the produced gas flow rate.

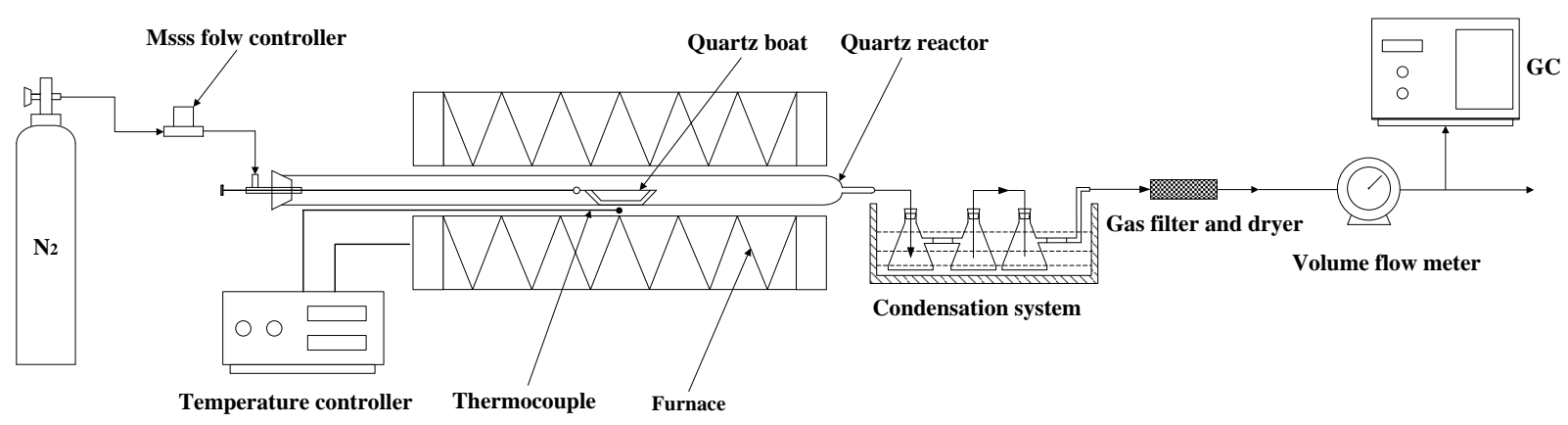

Fig. 1. Experimental system of sewage sludge pyrolysis

The reactor was heated to the target temperatures $\left(500,600,700,800,900{ }^{\circ} \mathrm{C}\right)$ at a temperature increasing slope of $20^{\circ} \mathrm{C} \cdot \mathrm{min}^{-1}$. A quartz boat containing $1 \pm 0.005 \mathrm{~g}$ of prepared sample was placed in the cool part of the reactor tube before each test. When the temperature reached the target value, a $\mathrm{N}_{2}$ flow of $100 \mathrm{ml} \cdot \mathrm{min}^{-1}$ was supplied and maintained by $30 \mathrm{mins}$ to guarantee on air in the reactor. After that, the quartz boat was rapidly pushed into the reaction zone at the target temperature in the reactor and the gas sampling started. The pyrolysis process of each sample lasted for 10 mins, after that, the quartz boat was pulled back to the cool region of the reactor, cold to room temperature in inert atmosphere, and then the solid residue was reserved for testing. The produced pyrolysis gas passed through the condensation unit to collect the condensed bio-oil and water. The total volume of the non-condensable gases was measured by a gas flow meter unit. The pyrolysis gas was collected periodically through the gas bags, and then analyzed by a gas chromatogragh (GC, Shimadzu 
GC-2014) to measure the concentrations of $\mathrm{CO}_{2}, \mathrm{CO}, \mathrm{H}_{2}, \mathrm{CH}_{4}$, and $\mathrm{C}_{2} \mathrm{H}_{\mathrm{m}}\left(\mathrm{C}_{2} \mathrm{H}_{2}, \mathrm{C}_{2} \mathrm{H}_{4}\right.$ and $\left.\mathrm{C}_{2} \mathrm{H}_{6}\right)$. After the pyrolysis process, the solid residue was collected and weighed. The absolute yield of each component in the pyrolysis gas was calculated by using the total gas volume and density of each component. The amount of the liquid fraction including condensed bio-oil and water was determined by the difference from the mass balance. All of the pyrolysis test conditions were repeated by two or three times to guarantee the repeatability. The average data were applied.

\subsection{Calculations}

\subsubsection{Reaction heat from DSC curves}

The heat from DSC curves mainly includes two parts: one is the heat necessary to heat sample, another is the heat required for the reaction $[19,20]$. The two parts can be presented with the following Eq. (1):

$$
\frac{d Q / d t}{m_{s, 0}}=\frac{m_{s} c_{p, s} d T / d t}{m_{s, 0}}+\frac{Q_{P}}{m_{s, 0}}
$$

where, $T(\mathrm{~K})$ is the reaction temperature, $t(\mathrm{~s})$ is the reaction time, $Q(\mathrm{~kJ})$ is the reaction heat of sample pyrolysis, $Q_{\mathrm{p}}\left(\mathrm{kJ} \cdot \mathrm{kg}^{-1} \cdot \mathrm{s}^{-1}\right)$ is the heat flow, $m_{\mathrm{s}, 0}(\mathrm{~kg})$ is the original mass of sample, $m_{\mathrm{s}}(\mathrm{kg})$ is the mass residue of sample at time $\left.t, c_{\mathrm{p}, \mathrm{s}}\left(\mathrm{kJ} \cdot \mathrm{kg}^{-1} \cdot \mathrm{K}^{-1}\right)\right)$ is the specific heat capacity of sample.

In Eq. (1),

$$
\frac{m_{s} c_{p, s} d T / d t}{m_{s, O}}<<\frac{Q_{P}}{m_{s, o}}
$$

According to Eq. (2), the reaction heat in Eq. (1) can be calculated by Eq. (3)

$$
\frac{d Q / d t}{m_{s, 0}}=\frac{Q_{P}}{m_{s, 0}}
$$

The result of Eq. (3) integration can be rewritten as Eq. (4):

$$
Q=\int_{0}^{t} Q_{p} d t
$$


Thus, the reaction heat of the sample pyrolysis can be calculated by integrating the DSC curves using Eq. (4). Here, the unit of reaction heat is $\mathrm{kJ} \cdot \mathrm{kg}^{-1}$.

\subsubsection{Synergetic effect calculation}

To investigate whether there is a synergetic effect in the co-pyrolysis of sewage sludge with wheat straw and illustrate their interaction mechanism, the theoretical value of the mixture pyrolysis is calculated by Eq. (5) according to the average weight of the individuals [21].

$$
Y_{\text {theoretical }}=\omega \times Y_{\text {straw }}+(1-\omega) \times Y_{\text {sludge }}
$$

Where $Y_{\text {theoretical }}$ is the weight-averaging theoretical value of the mixture pyrolysis; $\omega$ is wheat straw addition percentage, \%; $Y_{\text {straw }}$ is the experimental value of wheat straw pyrolysis; $Y_{\text {sludge }}$ is the experimental value of sewage sludge pyrolysis.

\section{Results and discussion}

\subsection{The synergetic effect in TGA analysis}

\subsubsection{Comparison between the pyrolysis of sewage sludge and wheat straw}

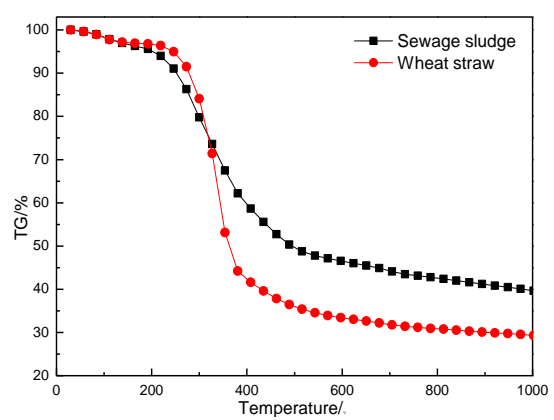

(a)

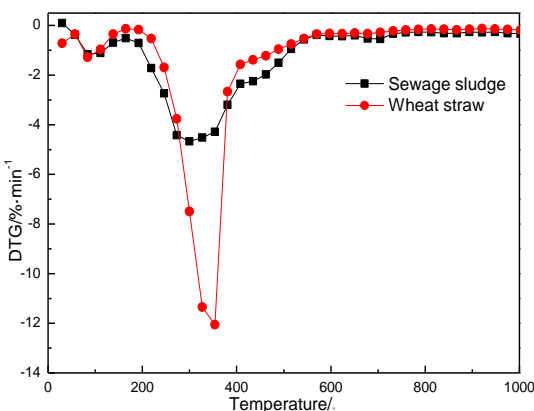

(b)

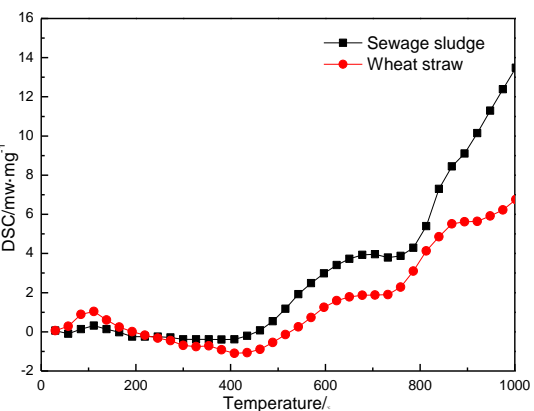

(c)

Fig. 2. Pyrolysis curves of sewage sludge and wheat straw: (a) TG; (b) DTG; (c) DSC

Fig. 2(a), 2(b) and 2(c) show the TG, DTG and DSC curves obtained in the pyrolysis process of sewage sludge and wheat straw at a heating of $20{ }^{\circ} \mathrm{C} \cdot \mathrm{min}^{-1}$, respectively. As illustrated in Fig. 2(a), the total mass loss of sewage sludge is lower than that of wheat straw due to the higher ash content of the former as shown in Table 1. During the pyrolysis process, the major mass loss and gas evolution 
occur simultaneously with continuous heating of sewage sludge and wheat straw [22]. The beginning and ending temperatures of the decomposition process are important pyrolysis characteristic parameters for a fuel. From Fig. 2(b), the beginning temperatures of sewage sludge and wheat straw are 180 and $200{ }^{\circ} \mathrm{C}$, and the corresponding ending temperatures are 600 and $570{ }^{\circ} \mathrm{C}$, respectively. The DTG peak corresponds to the yield of the volatile. Moreover, the maximum mass loss rate of wheat straw is much higher than that of sewage sludge. From Fig. 2(c), there is an endothermal peak of water evaporating from $30{ }^{\circ} \mathrm{C}$ to $200{ }^{\circ} \mathrm{C}$ in the DSC curves of both sewage sludge and wheat straw. Then, a small exothermic peak appears in the temperature range of $180-460{ }^{\circ} \mathrm{C}$ for sewage sludge, while it is in the range of $200-530^{\circ} \mathrm{C}$ for wheat straw. When the pyrolysis temperature is higher than 460 and $530{ }^{\circ} \mathrm{C}$, the DSC curves of both sewage sludge and wheat straw keep a continuous increasing.

\subsubsection{The interaction between sewage sludge and wheat straw}

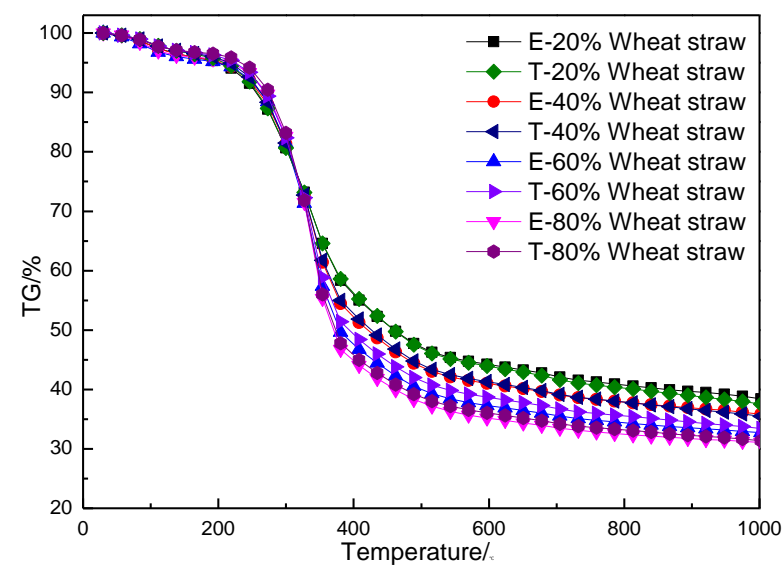

(a)

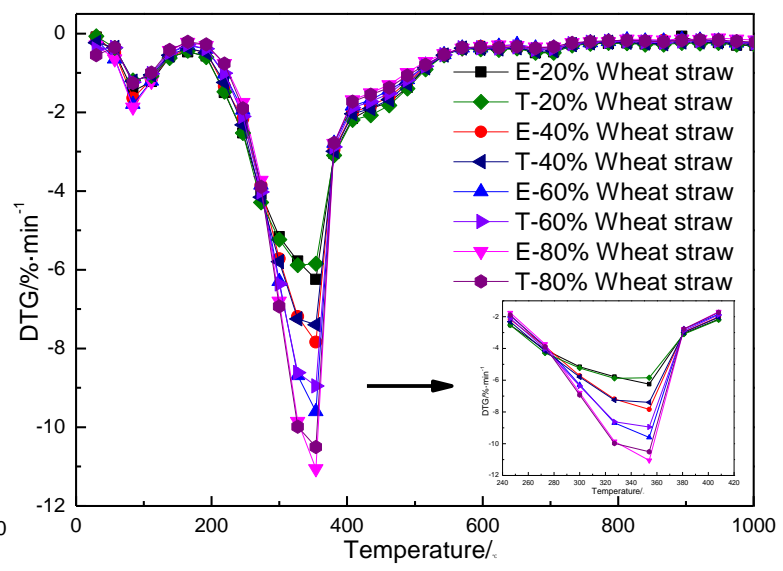

(b)

Fig. 3. Comparison of experimental and theoretical curves (E-experimental, T-theoretical): (a) TG; (b) DTG

Under different wheat straw addition percentages, the comparison of the experimental and theoretical TG curves is shown in Fig. 3(a). At the initial stage, the theoretical TG curves agree well with the experimental TG curves. However, the theoretical TG curves lag behind the experimental TG curves when the temperature is higher than $340{ }^{\circ} \mathrm{C}$, especially for the condition of $60 \%$ wheat 
straw addition, the deviation reaches the maximum. The experimental and theoretical DTG curves at different co-pyrolysis percentages are compared in Fig. 3(b), and the pyrolysis characteristic parameters are listed in Table 2 , where $T_{1}, T_{\text {peak }}$ and $T_{\mathrm{f}}$ are the beginning temperature, the temperature of the max decomposition rate, and the ending temperature, respectively. $\mathrm{DTG}_{\max }$ is the maximum mass loss rate, and the total mass loss is the mass loss when the thermal decomposition ends. $\Delta-\mathrm{DTG}_{\max }$ is the difference between experimental and theoretical DTG $\mathrm{max}_{\max }$ values. $\Delta$-total mass loss is the difference between experimental and theoretical total mass loss values. $\mathrm{E}$ and $\mathrm{T}$ refer to experimental and theoretical values, respectively. As observed in Table 2, with the increase of wheat straw percentages from 20 to $80 \%$ in the mixtures, the maximum mass loss rates of the experimental DTG curves were higher by $0.16,0.21,0.44$ and $0.33 \% \cdot \mathrm{min}^{-1}$ than the theoretical DTG curves, respectively.

Both the TG and DTG curves indicate that there might be a synergetic effect during co-pyrolysis of sewage sludge and wheat straw but it is weak in a TGA test. This synergetic effect has been interpreted as the interaction among the lipa, proteins and saccharides in the sewage sludge and alkali metals in the wheat straw during the co-pyrolysis process [23]. These alkali metals existed in wheat straw could decrease the yield of organic liquids and increase char and gas yield [24]. A large addition percentage of wheat straw promotes the cracking of larger molecular organic compounds and increases its contribution for synergetic effect.

Table 2 Pyrolysis characteristic parameters of sewage sludge/wheat straw mixtures

\begin{tabular}{|c|c|c|c|c|c|c|c|c|}
\hline Samples & $\mathrm{E} / \mathrm{T}$ & $\mathrm{T}_{1} /{ }^{\circ} \mathrm{C}$ & $\mathrm{T}_{\text {peak }} /{ }^{\circ} \mathrm{C}$ & $\mathrm{T}_{\mathrm{f}} /{ }^{\circ} \mathrm{C}$ & $\mathrm{DTG}_{\max } / \% \cdot \min ^{-1}$ & $\Delta-\mathrm{DTG}_{\max } / \% \cdot \min ^{-1}$ & $\begin{array}{c}\text { Total mass } \\
\text { loss } / \%\end{array}$ & $\begin{array}{c}\Delta \text {-total mass } \\
\text { loss } / \%\end{array}$ \\
\hline Sewage sludge & $\mathrm{E}$ & 180 & 288 & 740 & -4.87 & - & -60.27 & - \\
\hline \multirow{3}{*}{$20 \%$ Straw } & $\mathrm{E}$ & 180 & 347 & 726 & -6.70 & \multirow{3}{*}{-0.16} & -61.50 & \multirow{3}{*}{0.89} \\
\hline & & & & & & & & \\
\hline & $\mathrm{T}$ & 179 & 343 & 727 & -6.54 & & -62.39 & \\
\hline
\end{tabular}




\begin{tabular}{|c|c|c|c|c|c|c|c|c|}
\hline \multirow{3}{*}{$40 \%$ Straw } & $\mathrm{E}$ & 180 & 344 & 725 & -8.75 & \multirow{3}{*}{-0.21} & -64.12 & \multirow{3}{*}{0.34} \\
\hline & & & & & & & & \\
\hline & $\mathrm{T}$ & 180 & 344 & 719 & -8.54 & & -64.46 & \\
\hline \multirow{3}{*}{$60 \%$ Straw } & $\mathrm{E}$ & 177 & 346 & 608 & -11.03 & \multirow{3}{*}{-0.44} & -67.26 & \multirow{3}{*}{-0.73} \\
\hline & & & & & & & & \\
\hline & $\mathrm{T}$ & 181 & 344 & 603 & -10.59 & & -66.53 & \\
\hline \multirow{3}{*}{$80 \%$ Straw } & $\mathrm{E}$ & 183 & 345 & 609 & -13.01 & \multirow{3}{*}{-0.33} & -68.89 & \multirow{3}{*}{-0.3} \\
\hline & & & & & & & & \\
\hline & $\mathrm{T}$ & 182 & 344 & 602 & -12.68 & & -68.59 & \\
\hline Wheat straw & $\mathrm{E}$ & 200 & 344 & 570 & -14.66 & - & -70.61 & - \\
\hline
\end{tabular}

\subsection{The synergetic effect in the fixed-bed reactor}

\subsubsection{Pyrolysis of sewage sludge}

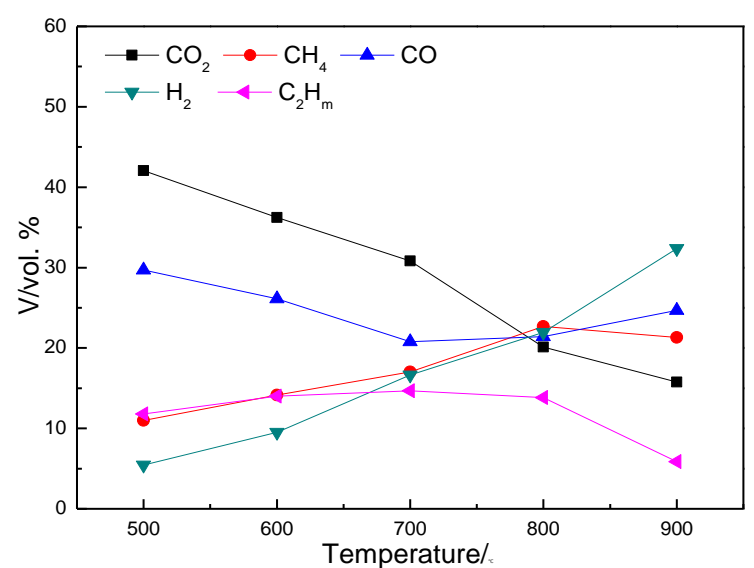

(a)

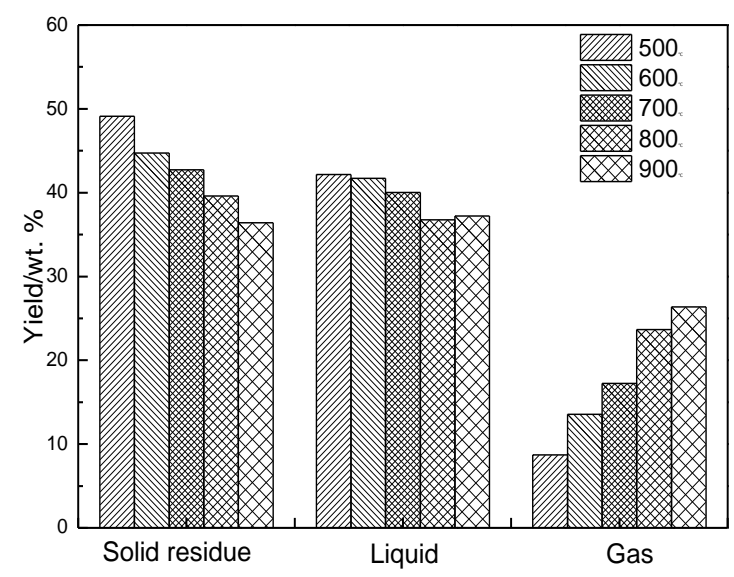

(b)

Fig. 4. Effect of temperature on the pyrolysis products of sewage sludge: (a) gas composition (b)

gas/liquid/solid phase distributions

Temperature is one of the most important parameters affecting the gas composition and product distributions. When sewage sludge decomposed alone at various temperatures, the gas composition and the distributions of the three-phase (gas, liquid, and solid residue) yields are shown in Fig. 4(a) and (b) respectively.

As shown in Fig. 4(a), the $\mathrm{H}_{2}$ content of the gas composition increases linearly with the pyrolysis temperature and reaches 32.4 vol. $\%$ at $900{ }^{\circ} \mathrm{C}$. With temperature increase from 500 to 900 ${ }^{\circ} \mathrm{C}$, the $\mathrm{CO}_{2}$ content decreases from 42.1 to 15.8 vol. $\%$, while the $\mathrm{CO}$ content first decreases and then 
increases, reaching the maximum of 20.8 vol. $\%$ at $700{ }^{\circ} \mathrm{C}$. The releases of $\mathrm{CO}$ and $\mathrm{CO}_{2}$ are attributed to the decomposition of oxygenated groups from carbohydrates, such as decarbonylation and decarboxylation [25]. The decarbonylation may mainly contribute to the release of $\mathrm{CO}$ while the decarboxylation to the release of $\mathrm{CO}_{2}$. The concentration of $\mathrm{CO}$ is the lowest at $700{ }^{\circ} \mathrm{C}$ because of the competitive reaction between $\mathrm{CO}$ and $\mathrm{CO}_{2}$. This indicates that the decarbonylation reaction might be weakened at about $700{ }^{\circ} \mathrm{C}$. As the pyrolysis temperature increases from 500 to $900{ }^{\circ} \mathrm{C}$, the $\mathrm{CH}_{4}$ content increased first and then decreased. It is in the range of $11.0-22.7$ vol.\%, reaching the maximum of 22.7 vol. $\%$ at $800{ }^{\circ} \mathrm{C}$. This is mainly due to the higher thermal cracking of tar and char conversion at higher temperatures, and high temperatures allow the release of more light gases such as $\mathrm{CH}_{4}$ and $\mathrm{C}_{2} \mathrm{H}_{m}$ [25]. This changing tendency is consistent with the report on the $\mathrm{CH}_{4}$ content by Inguanzo et al. [26], who obtained the maximum $\mathrm{CH}_{4}$ content of about 25 vol. $\%$ at $600{ }^{\circ} \mathrm{C}$ in the study of the influence of temperature on the gas composition from sewage sludge pyrolysis.

As shown in Fig. 4(b), with an increase of pyrolysis temperature from 500 to $900{ }^{\circ} \mathrm{C}$, the gas yield increases from 8.7 to 26.4 wt.\%, while the solid residue yield and the liquid yield decreased from 49.1 to 36.4 wt.\% and from 42.2 to 37.2 wt.\%, respectively. This is mainly because higher pyrolysis temperatures promote the thermal cracking and reforming of tars and increase the carbon conversion efficiency [9]. Increasing pyrolysis temperature also enhanced the thermal reforming reactions and the decomposition of heavy hydrocarbons. The gas components from sewage sludge pyrolysis could also react with each other and char, such as shifting reaction and tar cracking reaction, contributing to much more product gases. 


\subsubsection{Gas composition during the co-pyrolysis process}

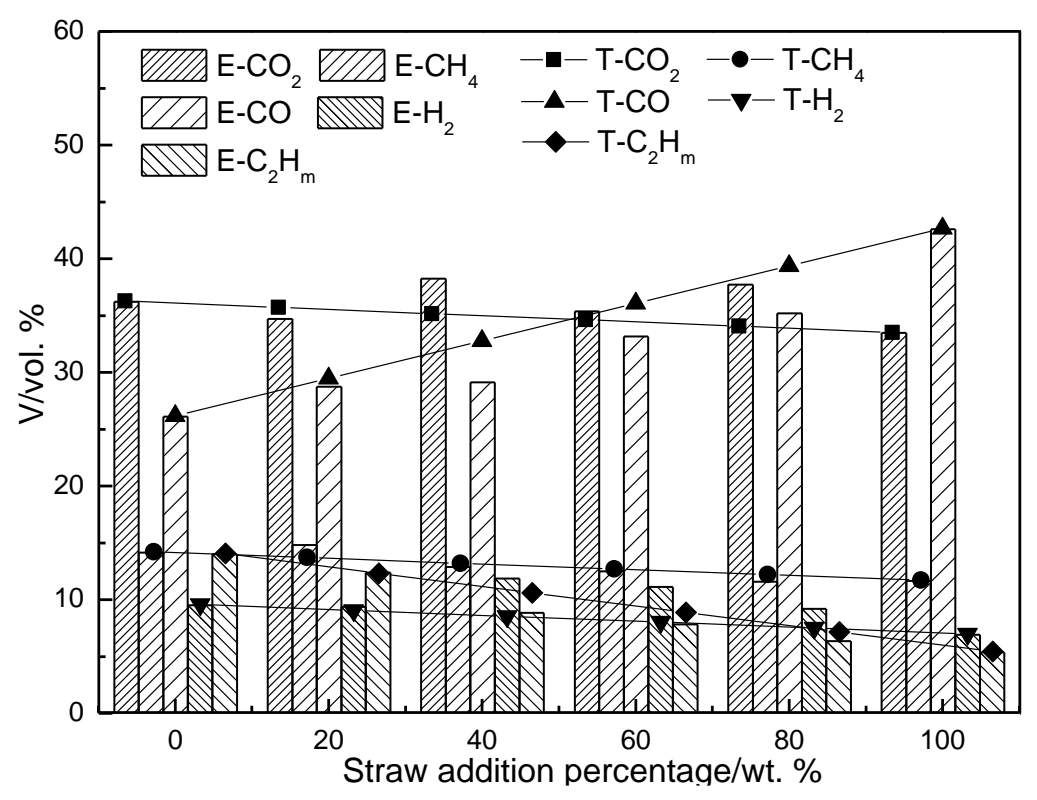

Fig. 5. Gas compositions of co-pyrolysis at different wheat straw addition percentages

(cylinder-experimental value, line and point-theoretical value)

The change of the gas composition at different wheat straw addition percentages during pyrolysis at $600{ }^{\circ} \mathrm{C}$ is shown in Fig. 5. As to sewage sludge pyrolysis, the $\mathrm{CO}_{2}, \mathrm{CO}, \mathrm{H}_{2}, \mathrm{CH}_{4}$ and $\mathrm{C}_{2} \mathrm{H}_{\mathrm{m}}$ volume contents are $36.2,26.1,9.5,14.1$, and 14.0 vol.\% respectively; while as to wheat straw pyrolysis, those are $33.5,42.6,6.9,11.6$, and 5.4 vol.\% respectively. This comparison proves that wheat straw pyrolysis tends to produce more gas, because the $\mathrm{CO}_{2}, \mathrm{CO}, \mathrm{H}_{2}, \mathrm{CH}_{4}$ and $\mathrm{C}_{2} \mathrm{H}_{\mathrm{m}}$ volume contents from sewage sludge pyrolysis are less than wheat straw pyrolysis. The CO volume content of gas from wheat straw pyrolysis is higher than sewage sludge pyrolysis by 16.5 vol.\%, while the volume content of $\mathrm{CO}_{2}$ from wheat straw pyrolysis was lower sewage sludge pyrolysis. These differences of gas component contents are mainly caused by the different chemical compositions between sewage sludge and wheat straw. Sewage sludge mainly contains three important components like lipa, proteins and saccharides, which are easier to be broken down when heated [27]. However, the three primary components of wheat straw are cellulose, hemicelluloses and lignin, which have 
high heat-stabilities and are hard to break down [28].

According to the equation (5), by weight-averaging each gas component content of sewage sludge and wheat straw pyrolysis alone (with wheat straw addition percentage of 0 and $100 \%$ ), the theoretically calculated gas compositions with the wheat straw addition percentages of 20, 40,60 and $80 \%$ are determined, plotted and compared with experimental results in Fig. 5. As observed for all the wheat straw addition percentages, the differences for the volume content of $\mathrm{CO}_{2}, \mathrm{CH}_{4}$ and $\mathrm{C}_{2} \mathrm{H}_{\mathrm{m}}$ between the theoretical calculation and experimental measurement are little. The synergetic effect of co-pyrolysis on $\mathrm{CH}_{4}$ and $\mathrm{C}_{2} \mathrm{H}_{\mathrm{m}}$ should be weak, whereas the synergetic effect on $\mathrm{CO}, \mathrm{CO}_{2}$ and $\mathrm{H}_{2}$ producing is indeed observed. It can be seen that the experimental values of CO content are always lower than the theoretical calculation values, and the difference between experimental and calculated values reached the maximum of 4.1 vol. $\%$ at a wheat straw addition percentage of $60 \%$. As to $\mathrm{CO}_{2}$ and $\mathrm{H}_{2}$ contents, their differences between theoretical and experimental values are mainly observed in the wheat straw addition percentage ranging in 40-80\%, and the difference reaches the maximum of 3.4 vol. $\%$ for $\mathrm{H}_{2}$ producing at the wheat straw addition percentage of $40 \%$. The above analysis indicates that there is a synergetic effect on the gas producing during the co-pyrolysis processes of sewage sludge and wheat straw. The synergetic effect is complicated and shows different impacts on each gas component. Generally, the synergetic effect in the co-pyrolysis of sewage sludge and wheat straw promotes the formation of $\mathrm{CO}_{2}$ and $\mathrm{H}_{2}$, inhibits the formation of $\mathrm{CO}$, but takes little influence on the formations of $\mathrm{CH}_{4}$ and $\mathrm{C}_{2} \mathrm{H}_{\mathrm{m}}$. 


\subsubsection{Gas/liquid/solid product distributions during the co-pyrolysis process}

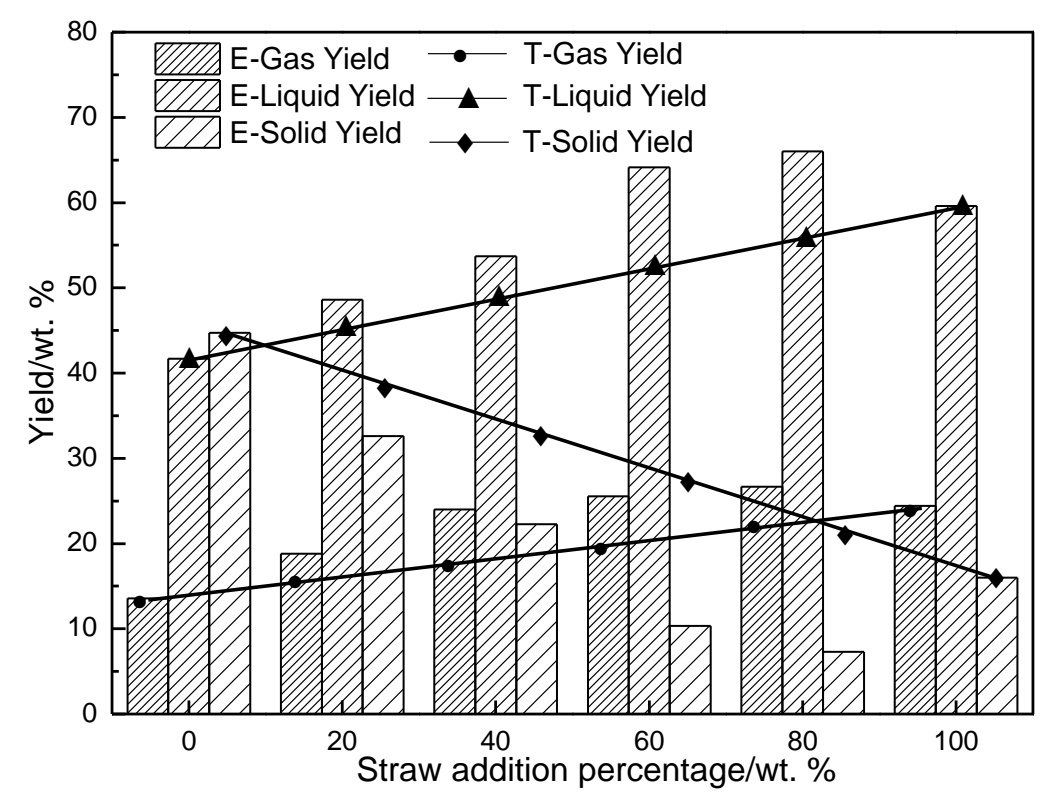

Fig. 6. Three-phase yields of co-pyrolysis during co-pyrolysis (cylinder-experimental value, line and point-theoretical value)

The gas/liquid/solid phase distributions during the co-pyrolysis process at different wheat straw addition percentages at $600{ }^{\circ} \mathrm{C}$ are shown in Fig. 6. The yields of gas, liquid and solid are 13.6, 41.7 and 44.7 wt.\% respectively when sewage sludge decomposes alone, whereas are 24.4, 59.6 and 16.01 wt.\% when wheat straw decomposes alone. This comparison indicates that the yields of gas and liquid from sewage sludge pyrolysis are lower than wheat straw pyrolysis, while the yield of solid from sewage sludge pyrolysis is higher than wheat straw pyrolysis by $28.7 \mathrm{wt} . \%$, attributing to the high ash content in sewage sludge [29]. With an increase of the wheat straw addition percentage from 20 to $80 \%$, the yield of the bio-fuel including liquid and gas increases from 67.4 to 92.7 wt. $\%$, while the solid residue yield decreases from 32.6 to $7.3 \mathrm{wt} . \%$. It is also observed that when wheat straw addition percentage is $80 \%$, the yield of bio-fuel including liquid and gas reaches the maximum corresponding to the minimum yield of the solid residue.

A synergetic effect analysis of the comparison between the experimental and theoretically 
calculated yields is also conducted in Fig. 6. It can be seen that the experimental yields of gas and liquid phase are conspicuously higher than theoretical calculation, while the experimental yield of solid phase is lower. This indicates that the synergetic effect greatly promotes the producing of gas and liquid phase but inhibits the producing of solid phase. This significant interaction should be attributed to the catalytic activity of the metals in the ashes of wheat straw or sewage sludge that promotes the secondary reactions such as cracking and dehydrogenation, resulting in increasing the gas and liquid yields and reducing the solid yield [30-32].

\subsection{The reaction heat analysis of co-pyrolysis}

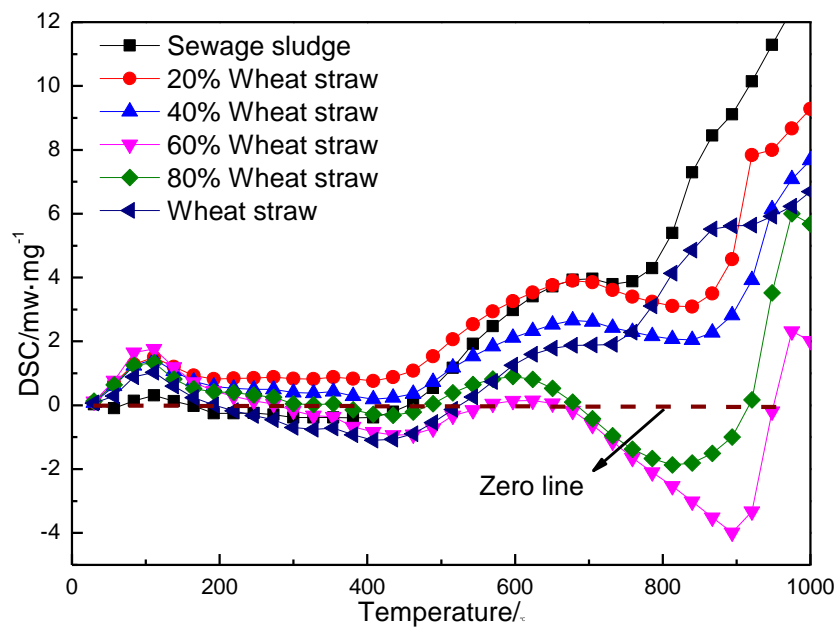

(a)

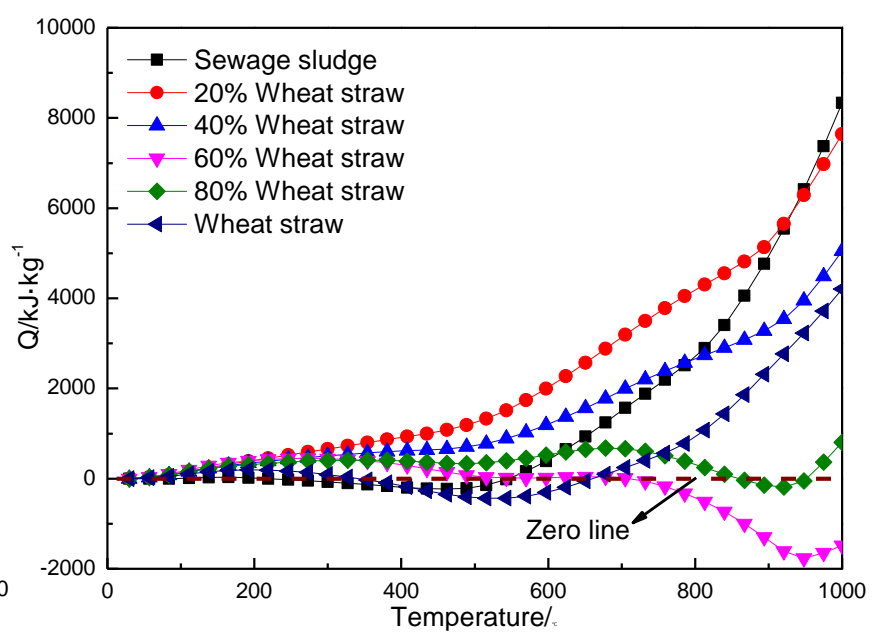

(b)

Fig. 7. The reaction heat analysis of co-pyrolysis: (a) DSC curves (b) required heat curves

The DSC curves and the integral heat requirement curves of the co-pyrolysis at different wheat straw addition percentages are plotted in Fig. 7(a) and 7(b) respectively. The positive and negative values of the curves in Fig. 7(a) and 7(b) stand for endothermic and exothermic conditions, respectively. The result of the time integral of a DSC curve in Fig. 7(b) is a curve of sample reaction heat in a definite temperature interval [20]. From Fig. 7(b), it can be seen that when sewage sludge and wheat straw were heated alone and decomposed from 30 to $1000{ }^{\circ} \mathrm{C}$, the required heat are 8333.5 
and $4203.0 \mathrm{~kJ} \cdot \mathrm{kg}^{-1}$, respectively. However, under the conditions of co-pyrolysis, the change of required heat with the wheat straw addition percentage is interesting and even shows a contrary effect at different blending percentages. When the wheat straw addition percentages are at 20 and $40 \%$, the required heat are 7644.1 and $5050.7 \mathrm{~kJ} \cdot \mathrm{kg}^{-1}$ respectively; when at $60 \%$, the required heat is negative as $1484.6 \mathrm{~kJ} \cdot \mathrm{kg}^{-1}$; when at $80 \%$, the required heat is lowered to only $808.1 \mathrm{~kJ} \cdot \mathrm{kg}^{-1}$.

Such a changing trend of the required heat in co-pyrolysis in Fig. 7(b) could be easily understood from the DSC curves in Fig. 7(a) and Fig. 3(b). The primary decomposition is finished (Fig. 3b) and there is no significant difference among DSC curves of each condition (Fig. 7a) before $600{ }^{\circ} \mathrm{C}$. However, when the temperature increases above $600{ }^{\circ} \mathrm{C}$, even if the differential mass loss rate is very small (Fig. 3b), but the DSC curves in Fig. 7(a) shows a significant difference between the conditions of pyrolysis alone and co-pyrolysis. It can be seen that the DSC curves of both sewage sludge and wheat straw pyrolysis alone generally maintain monotonously increasing, however, once the condition of pyrolysis alone is switched to co-pyrolysis, a significant decreasing of DSC curves appears in the range of $700-900{ }^{\circ} \mathrm{C}$. This definitely proves the exothermic reactions occurring between the ash components of sewage sludge and wheat straw in this temperature range $[27,31]$. The synergetic effect of heat requirement found during the co-pyrolysis of sewage sludge and wheat straw shown in Fig. 7(b) is very important to the energy balance design of the pyrolysis system of sewage sludge with wheat straw addition, and these curves are helpful to provide reference and instruction to develop more efficient sludge pyrolysis system.

\section{Conclusions}

(1) The synergetic effect during the co-pyrolysis processes of sewage sludge and wheat straw is weak over a wide range of temperature from $30-1000{ }^{\circ} \mathrm{C}$ in thermogravimetric analysis. 
However, this synergetic effect can be clearly observed in a fixed-bed reactor by measuring the gas composition and gas/liquid/solid phase products, which results in an increase of the gas and liquid yields and a decrease of the solid residue yield.

(2) For the sewage sludge pyrolysis, increasing temperature increases the gas yield but decreases the liquid and char yields. The adding percentages of wheat straw significantly affect the gas composition and the synergetic effect degree. The strongest synergetic effect of sewage sludge and wheat straw co-pyrolysis is observed at the wheat straw percentage of $60 \%$.

(3) The heat requirement analysis on the co-pyrolysis process of sewage sludge and wheat straw demonstrates the strong synergetic exothermic reactions between the ashes of two samples. These curves of the heat requirement obtained by DSC analysis are helpful to provide reference and instruction to develop more efficient sludge pyrolysis system.

\section{Acknowledgements}

This study was supported by the Natural Science Foundation of China (Grant Nos. 51376147 and 51306142).

\section{References}

[1] Smith KM, Fowler GD, Pullket S, Graham NJD. Sewage sludge-based adsorbents: a review of their production, properties and use in water treatment applications. Water Res, 2009;43(10):2569-2594.

[2] Moon J, Mun, TY, Yang W, Lee U, Hwang J, Jang E, Choi C. Effects of hydrothermal treatment of sewage sludge on pyrolysis and steam gasification. Energ Convers Manage 2015;103:401-407.

[3] Li H, Chen Z, Huo C, Hu M, Guo D, Xiao B. Effect of bioleaching on hydrogen-rich gas 
production by steam gasification of sewage sludge. Energ Convers Manage, 2015;106:1212-1218.

[4] Azuara M, Fonts I, Bimbela F, Murillo MB, Gea G. Catalytic post-treatment of the vapors from sewage sludge pyrolysis by means of $\gamma-\mathrm{Al}_{2} \mathrm{O}_{3}$ : Effect on the liquid product properties. Fuel Process Technol 2015;130:252-262.

[5] Kan T, Strezov V and Evans T. Effect of the Heating Rate on the Thermochemical Behavior and Biofuel Properties of Sewage Sludge Pyrolysis. Energ Fuel 2016;30(3):1564-1570.

[6] Shen L, Zhang DK. An experimental study of oil recovery from sewage sludge by low-temperature pyrolysis in a fluidised-bed. Fuel 2003;82(4):465-472.

[7] Lu Q, Li WZ, Zhu XF. Overview of fuel properties of biomass fast pyrolysis oils. Energ Convers Manage 2009;50:1376-1383.

[8] Shao J, Yan R, Chen H, Wang B, Lee DH, Liang DT. Pyrolysis Characteristics and Kinetics of Sewage Sludge by Thermogravimetry Fourier Transform Infrared Analysis. Energ Fuel 2007;22(1):38-45.

[9] Fonts I, Gea G, Azuara M, Abrego Javier, Arauzo J. Sewage sludge pyrolysis for liquid production: a review. Renew Sust Energ Rev 2012;16(5):2781-2805.

[10] Inguanzo M, Dominguez A, Menéndez JA, Blanco CG, Pis JJ. On the pyrolysis of sewage sludge: the influence of pyrolysis conditions on solid, liquid and gas fractions. J Anal Appl Pyrol 2002;63(1):209-222.

[11] Manara P, Zabaniotou A. Towards sewage sludge based biofuels via thermochemical conversion-a review. Renew Sust Energ Rev 2012;16(5):2566-2582.

[12] Ding HS, Jiang H. Self-heating co-pyrolysis of excessive activated sludge with waste biomass: 
Energy balance and sludge reduction. Bioresource Technol 2013;133:16-22.

[13] Fang S, Yu Z, Lin Y, Hu S, Liao Y, Ma X. Thermogravimetric analysis of the co-pyrolysis of paper sludge and municipal solid waste. Energ Convers Manage 2015;101:626-631.

[14] Zhang W, Yuan C, Xu J, Yang X. Beneficial synergetic effect on gas production during co-pyrolysis of sewage sludge and biomass in a vacuum reactor. Bioresource Technol $2015 ; 183: 255-258$.

[15] Samanya J, Hornung A, Apfelbacher A, Vale P. Characteristics of the upper phase of bio-oil obtained from co-pyrolysis of sewage sludge with wood, rapeseed and straw. J Anal Appl Pyrol 2012;94:120-125.

[16] Huang YF, Shih CH, Chiueh PT, Lo SL. Microwave co-pyrolysis of sewage sludge and rice straw. Energy 2015;87:638-644.

[17] Zhu X, Chen Z, Xiao B, Hu Z, Hu M, Liu C, Zhang Q. Co-pyrolysis behaviors and kinetics of sewage sludge and pine sawdust blends under non-isothermal conditions. J Therm Anal Calorim 2014;119(3):2269-2279.

[18] Salleh F, Samsuddin R, Husin M. Bio-Fuel Source from Combination Feed of Sewage Sludge and Rice Waste. International Conference on Environment Science and Engineering 2011;8:68-72.

[19] He, F, Yi, W, Zha, J. Measurement of the heat of smoldering combustion in straws and stalks by means of simultaneous thermal analysis. Biomass Bioenerg 2009;33 (1):130-136.

[20] He F, Xu L, Bai X, Cai J, Yi W. Heat Requirement of Biomass Pyrolysis. Acta Energiae Solaris Sinica 2006;27 (3), 237-241.

[21] Aboulkas A, El Harfi K, El Bouadili A. Pyrolysis of olive residue/low density polyethylene 
mixture: Part I Thermogravimetric kinetics. J Fuel Chem Technol 2008;36(6): 672-678.

[22] Jayaraman K, Gökalp I. Pyrolysis, combustion and gasification characteristics of miscanthus and sewage sludge. Energ Convers Manage 2015;89:83-91.

[23] Jia XR, Jin BS, Li R. TG-FTIR Study on Pyrolysis of Sewage Sludge. Boiler Technology 2009 40:77-80.

[24] Fahmi R, Bridgwater AV, Donnison I, Yates N, Jones JM. The effect of lignin and inorganic species in biomass on pyrolysis oil yields, quality and stability. Fuel, 2008;87(7):1230-1240.

[25] Fan H, Zhou H, Wang J. Pyrolysis of municipal sewage sludges in a slowly heating and gas sweeping fixed-bed reactor. Energ Convers Manage 2014;88:1151-1158.

[26] Inguanzo M, Dom $\square \square$ nguez A, Menéndez JA, Blanco CG, Pis JJ. On the pyrolysis of sewage sludge: the influence of pyrolysis conditions on solid, liquid and gas fractions. J Anal Appl Pyrol 2002;63(1):209-222.

[27] Werther J, Ogada T. Sewage sludge combustion. Progress in energy and combustion science 1999;25(1):55-116.

[28] Chen HZ, Liu ZH. Multilevel composition fractionation process for high-value utilization of wheat straw cellulose. Biotechnol Biofuels 2014;7(1):137

[29] Fonts I, Azuara M, Gea G, Murillo MB. Study of the pyrolysis liquids obtained from different sewage sludge. J Anal Appl Pyrol 2009;85(1):184-191.

[30] Nigam J N. Ethanol production from wheat straw hemicellulose hydrolysate by Pichia stipitis[J]. J Biotechnol 2001;87(1):17-27.

[31] Wei X, Schnell U, Hein KRG. Behaviour of gaseous chlorine and alkali metals during biomass thermal utilisation. Fuel 2005;84(7):841-848. 
[32] Alvarez J, Amutio M, Lopez G, Bilbao J, Olazar M. Fast co-pyrolysis of sewage sludge and lignocellulosic biomass in a conical spouted bed reactor. Fuel 2015;159:810-818. 